ISSN: 2162-3104 Print/ ISSN: 2166-3750 Online Volume 7 Number 1 (2017), pp. 94-112 (C) Journal of International Students http://jistudents.org/

\title{
Collectivists’ Decision-Making: Saudi Arabian Graduate Students' Study Abroad Choices
}

\author{
Tamara Yakaboski \\ University of Northern Colorado, USA \\ Karla Perez-Velez \\ University of Northern Colorado, USA \\ Yousef Almutairi \\ University of Northern Colorado, USA
}

\begin{abstract}
The authors in this qualitative study explored how Saudi Arabian students selected a teaching focused research institution by examining Kingdom of Saudi Arabia and U.S. national influences, institutional factors, and personal influencers. Despite the continued rise in Saudi Arabian students studying at U.S. universities, limited published research exists on this unique student population. This study on Saudi graduate students reconceptualizes the homogenous perspectives on international student mobility. It demonstrates that study abroad decisions are not made from just push-pull or economic factors but through culturally specific social processes involving various actors both in and beyond their home country as well as intermediaries that is indicative of a more collectivist society.
\end{abstract}

Keywords: Saudi Arabia, student mobility, college choice , international students

International student decisions to migrate for graduate degrees are not only made at the individual or family level but can be highly influenced and even driven, by employers and governmental entities. Adding to the complexity of college choice is how international graduate students select institutions that lack a global ranking or reputation. The perspectives of two commonly applied theories in international student mobility studies, push-pull (Mazzarol \& Soutar, 2002) and human capital (Becker, 1993), focus mostly 
on private benefits to the individual and public benefits for the home nation state. However they fail to illuminate more nuanced or culturally specific reasons why individuals participate in study abroad and where they end up studying. Recent research within the international student mobility literature has looked at the influence of international study abroad scholarships funded by governmental programs (Perna, Orosz, Gopaul, Jumakulov, Ashirbekov, \& Kishkentayeva, 2014; Perna, Orosz, Jumakulov, Kishkentayeva, \& Ashirbekov, 2015). These programs are seen as governmental "intervention" that increases student participation in transnational higher education and play a role in student study abroad decisions (Paulsen, 2001; Perna, et al, 2015).

The Kingdom of Saudi Arabia (KSA) has developed a successful government scholarship program through its commitment to the Saudi Arabian education systems by educating citizens overseas in needed fields of study. The KSA invests over $\$ 2$ billion dollars annually to fund the main international scholarship program, The King Abdullah Scholarship Program (KASP). The King Abdullah Scholarship Program (active from 2005 2020) is an international scholarship program funded and run by the Saudi government to provide quality higher education for qualified Saudis, to bring about high levels of academic and professional standards, exchange culture with other countries and build up a qualified and professional Saudi staff and faculty (Hall, 2013). Additionally, many Saudi higher education institutions also fund their employees to study abroad for advanced degrees through institutional or employer sponsored scholarship programs (Higher Education Council of Saudi Arabia, 1997).

The Saudi Arabian Cultural Mission (SACM) administers all KSA scholarship programs and functions as the intermediary between U.S. institutions and their counterparts in the KSA (SACM, n.d.). As with all Saudi funded scholarships, students face a limit of which academic fields and degree types the government will cover and they have a return obligation, where recipients much return back to KSA after degree completion (Perna, et al., 2014). While these governmental funding programs are quite influential as in the case for Saudi students, they are not absolute influencers on institutional choice.

The KSA is the fourth largest sender of students to the U.S. for higher education for five years in a row, just behind China, India, and South Korea, and over $20 \%$ of these Saudi Arabian students are at the graduate level (Institute of International Education, 2015). Saudi students will continue to study in the U.S. in steady numbers at least until 2020 when the scholarship program is set to expire. Yet, even with the continuous rise in Saudi Arabian students studying at doctoral/research universities (DRU) in the U.S. since the scholarship programs began, limited published research exists on what influences these student's study abroad decisions as well as 
their national and institutional selections. While the Saudi Ministry of Higher Education maintains a recommended list of approved universities, this alone does not explain how Saudi students find their way to a DRU that lacks a worldwide reputation and is more teaching focused. Therefore, the purpose of this study was to explore Saudi student mobility at national, institutional, and personal levels related to their decision making about institutional choice.

\section{LITERATURE REVIEW}

The majority of international student mobility research focuses on national level economic or education determinants rather than the individual level (Becker \& Kolster, 2012; Shanka, Quintal \& MEdMan, 2006; Wei, 2013) and some studies look at institutional choice as a by-product of national choice (Chen, 2007; Lee, 2008). The decision to study in the U.S. over other countries includes reasons, such as improving English language abilities (Eder, Smith, \& Pitts, 2010), economic factors (Wei, 2013), feelings of safety (Lee, 2008; Shanka et al., 2006; Urias \& Yeakey, 2009), and the desire to experience the American culture (Eder, et al., 2010). For graduate students specifically a U.S. doctoral degree implies an increase in opportunities as well as research training (Zhou, 2015).

International students choose their institutional host site based on a variety of factors and which factors have the most influence on a student depends on their background and reasons for studying overseas (Bista \& Dagley, 2015; Lee, 2008). Two common reasons are prestige and national ranking of institutions (Lee, 2008). Other researchers have found that the use of recruiters (Becker \& Kolster, 2012; Hagedorn \& Zhang, 2011), family and friend recommendations and networks (Eder, et al., 2010; Pimpa, 2003), and marketing (Lee, 2008; Shanka et al., 2006) all play roles in informing the decision making process for international students studying in the U.S. Location of the institutions in terms of cost of living or proximity to urban environments or their home countries have also been found as a minor influence (Lee, 2008; Shanka et al., 2006; Wilkins \& Huisman, 2011).

\section{Saudi Students as International Students}

The literature on Saudi higher education students studying abroad focuses on benefits of studying overseas (Heyn, 2013; Hofer, 2009) and challenges with adjustment, academics, and values (Al-Nusair, 2000; Rasheed, 1972; Shaw, 2010). Heyn's (2013) dissertation confirmed limited research on Saudi students studying in the U.S. Heyn indicated that 17 studies have been quantitative studies and five have been qualitative studies all dedicated to Saudi students' experiences and learning in the classroom 
and many of these are dissertations. Also, these 22 studies were published over more than a 30-year time period, thus leaving researchers with an incomplete understanding of current Saudi students' institutional choice and study abroad decision-making.

The few studies that have examined choice and reasons for studying in the U.S. found that KSA government policies and current Saudi faculty in KSA both play an important role (Denman \& Hilal, 2011; Hall, 2013; Onsman, 2012). Considering some version of a scholarship program has been available over the last few decades and many current faculty at Saudi Arabian universities were educated in the West, primarily in the U.S. (Onsman, 2012), these same faculty may encourage their students to attend their alma maters. One study limited to Saudi men found three dominant reasons for studying in the U.S.: family ties, prestige of American universities, and policies of the KASP (Hall, 2013). Another study identified policies that might influence which country Saudi students choose for higher education and explain mobility patterns (Denman \& Hilal, 2011). Given the increase of Saudi students studying overseas, this study attempts to bridge the gap by offering a qualitative exploration into choice and decisionmaking beyond just using governmental policies as the main or sole influencer.

\section{RESEARCH METHOD}

\section{Theoretical Framework}

Much of the research on international students' choice to study in the U.S. has developed from push-pull migration theory (Lee, 1966). The tendency is to view study abroad decisions as one directional; some factors push students out of their home countries while others pull or entice students to specific host countries (Altbach, 2004; Chen, 2007; Eder et al., 2010; Mazzarol \& Soutar, 2002; Wilkins \& Huisman, 2011). Some studies suggest that this framework fails to understand the complexity and nuances with student mobility decisions (Lee, 2008; Yakaboski, 2013) and views international students as a homogenous group (Gargano, 2009). Human capital theory often is used in conjunction with push-pull theory and assumes that students study abroad because it benefits them directly either monetarily or in other ways, such as enjoyment or adventure (Becker, 1993). This presents a narrow understanding of influences and students.

On the other hand, transnationalism theory explains structural factors in international student mobility and work that is more recent has argued for using it to examine students working with and within structures across borders (Schneider, 2013). Transnationalism considers that international students exist in transnational social fields with interlocking networks of ideas, practices, and social networks (Gargano, 2009). Student 
mobility and migration through a lens of transnationalism is about not only material or financial transactions and gains but symbolic or cultural meaning (Brooks \& Waters, 2011). Transnationalism focuses on processes that are not linear but highlights how multiple actors and structures may influence students' choices or how they may not view decisions as their choices but decisions of other people or entities. Transnationalism helps to explain the interplay between the international scholarship programs of KASP, SACM, and Saudi institutions, U.S. institutions and students and their families as well as cultural, religious, and gendered influences.

Given the unique interplay of national and cultural influences with Saudi graduate student choice, this research sought to answer the following research questions:

1. How do Saudi Arabian graduate students make study abroad decisions at national, institutional, and personal levels when sponsored by Saudi-based programs funded by either the government or employers?

2. How are Saudi Arabian graduate students' study abroad decisions influenced by culture, religion, and gender?

\section{RESEARCH METHOD}

We used an interpretivist exploratory qualitative design due to a limited foundation of literature on Saudi graduate student decisions and institutional selection or choice (Creswell, 2014; Lincoln, Lynham, \& Guba, 2011). Interpretivism seeks to understand and interpret the lived experiences of participants and uses these experiences to inform praxis (Lincoln, et al., 2011). Interpretivism also identifies meaning as socially constructed and interpreted by participants through interactions with their world, which was important in order to not analyze the stories through a Western perspective (Broido \& Manning, 2002; Merriam, 2009).

\section{Participants}

We gathered data for this study from one mid-sized research university (MRU) in the Western region of the United States. MRU is located in a state among the ten highest for enrollment of Saudi students (SACM, n.d.). Yet, the institution is a mid-sized, more teaching focused research institution that enrolls a small but growing number of international students with Saudi Arabia as the largest sender. Of the university enrollment, international students (undergraduate and graduate) make up only three percent of the student body representing 21 different countries at the graduate level and 34 countries at the undergraduate level (MRU Impact Profile, 2014). Saudi students consist of the largest population with a total of 164 Saudi students of the 367 international students at both undergraduate 
and graduate levels. Half of the Saudi students are at the graduate level hence the decision to focus on the masters and doctoral degree seeking students as opposed to those enrolled in undergraduate programs or the institution's English as a second language program. Of the 84 total Saudi graduate student population exactly half are women.

\begin{tabular}{|c|c|c|c|c|c|}
\hline Pseudonym & Sex & Degree level & Program of study & Age & $\begin{array}{l}\text { Marriage } \\
\text { status }\end{array}$ \\
\hline Ali & Male & Master & Special Education & 25 & Married \\
\hline Fahd & Male & Professional & Nursing & 34 & Married \\
\hline Omar & Male & $\mathrm{PhD}$ & Education Technology & $\mathrm{n} / \mathrm{a}$ & Married \\
\hline Majed & Male & $\mathrm{PhD}$ & Education Technology & 28 & Married \\
\hline Ahmed & Male & Master & Special Education & 25 & Single \\
\hline Marwan & Male & Master & Psychology & 24 & Single \\
\hline Essa & Male & Master & Special Education & 30 & Single \\
\hline Saad & Male & $\mathrm{PhD}$ & Applied Statistics & 34 & Married \\
\hline Bandar & Male & Master & Psychology & 26 & Married \\
\hline Reem & Female & $\mathrm{PhD}$ & Special Education & $\mathrm{n} / \mathrm{a}$ & Did not share \\
\hline Lamia & Female & $\mathrm{PhD}$ & Psychology & $\mathrm{n} / \mathrm{a}$ & Single \\
\hline Rana & Female & $\mathrm{PhD}$ & Education Technology & $\mathrm{n} / \mathrm{a}$ & Married \\
\hline Nasser & Male & $\mathrm{PhD}$ & Special Education & 32 & Married \\
\hline Yaser & Male & $\mathrm{PhD}$ & Education Technology & 40 & Married \\
\hline Atif & Male & Master & Special Education & 25 & Married \\
\hline Mohanad & Male & Master & Education Leadership & 42 & Married \\
\hline Saif & Male & Master & Education Technology & 25 & Single \\
\hline Ghada & Female & Master & Education Technology & $\mathrm{n} / \mathrm{a}$ & Single \\
\hline
\end{tabular}

After receiving institutional IRB approval, we invited Saudi students via emails sent by MRU's international student office requesting their participation as well as personal invitations from one of the researchers. 
Eighteen Saudi graduate students were interviewed, eight doctoral, nine masters, and one graduate level professional degree. All Saudi students received pseudonyms to protect their confidentiality. See Table 1 for names used and demographics. Even though the research team was mixed-gender, it was much easier to recruit male students to participate. As a result, the final sample included 14 male and four female participants. All were on full scholarship from the government, KASP (8), or their employer institution (10). The participants who were on institutional scholarship were teaching faculty at Saudi higher education institutions and were working on terminal degrees in the U.S.

\section{Data Collection and Analysis}

We followed the principles of qualitative research and case study methods to conduct semi-structured interviews, which allowed the participants and researchers to move freely from the initial questions to other emergent topics and allowed the participant or researcher to probe deeper into responses or further explain interview questions (Merriam, 2009). By conducting one hour face-to-face interviews, we were able to develop themes about decisions and choices made by Saudi graduate students that may guide future quantitative research. The participants were interviewed in English instead of their native language but one of the researchers served as an insider member and key informant that assisted in not only identifying participants but advising the team in cultural considerations and assisting with language challenges (Jones, Torres, \& Armino, 2006). Due to cultural and religious factors, the Saudi researcher, as a male, interviewed the male students and the other two researchers as females interviewed the Saudi women students.

To support the rigor and trustworthiness of the study given a member of the team was an insider, the research team engaged in researcher reflexivity (Jones, et al., 2006) assessing our integrity as a research team via an audit trail and being explicit with our research design (Gibbs, 2007). Transnationalism theory provided an analysis framework that pushed the research team to think beyond a Western perspective and to incorporate a variety of considerations from cultural, religious, gender, societal, and governmental influences. All members of the research team developed codes and themes and then shared responses for inter-rater reliability (Maxwell, 2004; Patton, 2001). We resolved any coding and analysis differences by discussing Western versus Middle Eastern cultural understandings and interpretations until we reached consensus. For this study's participants, the most significant influencers functioned at the national, institutional, and societal levels and were influenced by culture, gender, and religion. 


\section{RESULTS}

\section{U.S. and KSA National Level Influences}

A narrative of U.S. prestige and quality education. Institutional rankings and ratings seemed to matter less to these participants as they relied more heavily on the known narrative that U.S. degrees were more prestigious and of good quality compared to other countries, including their own. Reem shared that,

It was my dream to come here and study in the USA. I found the USA [degree] is, like, more valuable in Saudi Arabia. That study in the USA is more valuable because it [is from a] very good university, very high-ranking university and a good community, a good educational system here in USA so that's why they [SACM] encourage us to come to the USA.

Yet, for Bandar, studying in the U.S. was not his dream but rather something he felt pressured to do by his university employer:

I didn't have a choice to study in another country, even my country, which is home because my university wanted me to get a strong academic experience, which they believe the United States has more powerful academics than my country, especially in [specific social science field].

Some participants reinforced the value of learning English as a global language (Elyas, 2008) and experiencing cultures. Saad shared, "since the English language is a world language it will open resources for me, I can find more resources." As Marwan said, "unless you have experience, you have to go outside of your country, especially to the United States and engage with the different cultures and gain new experiences.”

While it is not new that the participants considered it prestigious to study in the U.S., one of the women expressed a gendered perspective to the prestige. Lamia explained,

It [Saudi students studying overseas] used to be very rare but now I think people are now used to the idea that, "yes, my son and my daughter are studying abroad, and that's okay.” But for conservative families this is not okay, I mean, even if the government is sending us. But I think it's viewed positively for males that, yes, you will continue your education. For girls, it's not same, some of my uncles, they still question my father, like, "what is she doing there?” but my 
mom and all the females in my family like my aunts, they're excited because this has a real benefit.

Prestige and family pride may not be universal when viewing study abroad through a gendered, cultural perspective.

Absence of graduate programs and quality ones in Saudi Arabia. The limited number of graduate level programs in Saudi Arabia required that students leave their homes to gain terminal degrees in order to return and grow Saudi Arabian programs and institutions. Participants often expressed these decisions as feeling that they did not have a choice in going overseas but rather that their institutions required them to temporarily migrate for graduate education and then return to their job, which was especially the case for the ten participants on institutional scholarship. Even the other eight with KASP funding discussed the common goal of returning after graduation and obtaining faculty positions in KSA higher education institutions. A few of the participants discussed opportunity in the recent growth of master's level educational programs in fields that might not have existed when they were undergraduate students in Saudi Arabia, such as educational technology or special education.

It is a common strategy for a country to send students overseas for advanced education when growing its own higher education system. As Saudi departments and institutions expand, fewer students will study overseas once they have the capacity and ability to train their own graduate students. This is already shifting as Lamia expressed:

Because our universities don't have graduate degrees. If you have a doctorate, you must get it from outside so that's why they send people, mostly graduate students, because we didn't have the programs. We didn't have schools teaching but now since I mean, new graduates came home so now we have [graduate programs]. So in my school that I graduated from, they still don't have educational psychology doctorate programs but I think they do you have a masters program.

Educating graduate students overseas is a useful strategy when a government requires that students return home after completing their studies, such as what all Saudi Arabian scholarships require, which also helps to prevent brain drain.

Another program concern is a perceived lower quality of educational programs in Saudi Arabia due partially to a lack of focus on research, which was seen as a strength to studying in the U.S. Lamia offered a view on the absence of research in Saudi Arabia: 
One of the things that I noticed about Saudi Arabia is that they don't focus on research. So when I arrived [in the U.S.], for example, I Googled motivation and international students. Most of the research, if it was done in the Middle East, it would be done either in Israel, Egypt, United Arab Emirates, so Saudi Arabia is not really focused on research. Which is sad because we need some research institutions ... and I think that we have to consider that back home and start the research movement.

Saif expressed the need for Saudi institutions to incorporate other practices and knowledge that can be gained abroad:

I'm an administrator at a university in Saudi Arabia, that is my country, and actually we need to improve our education in Saudi Arabia and I would like to merge some of the education from another countries, like the United States, to our Arabic education.

Participants viewed U.S. graduate education as an opportunity to develop KSA educational systems and knowledge. The participants were aware that they were helping to grow and improve Saudi higher education programs through their transnational temporary migration.

Saudi government or institutional sponsors. While the Saudi Ministry of Higher Education maintains lists of approved U.S. educational programs and institutions, it is the financial sponsors, through either KASP or individual institutions, who influence both institutional and program of study choice. All Saudi scholarship programs stipulate that students cannot change their majors without prior sponsor approval and justification (SACM, n.d.). Three participants discussed how they had wanted to study one field but were told to study in a different, related field by their sponsor or government. As Reem expressed, "I get accepted in psychology and educational technology but my sponsor wants me to study gifted education, specifically, they didn't accept my change of major." Saad explained this as the need for certain majors and not for others in Saudi Arabia. Given that ten of the participants were on institutional/employer scholarships and that they will return to their university jobs, these students need to have graduate degrees that their home departments can support and use.

Regardless of the prestige associated with studying in the U.S., some students preferred to have stayed in their home country for graduate education. Atif said, "if I have a chance to study inside my country, I would go there and I still want to go there. I didn't have an option.” Also, Ahmed said, "they [Saudi institutional employer] did not let me. I want to study there because I wanted to stay with my family but they won't let me. My 
advisor didn't let me study in Saudi Arabia so I had to study in the United States, so I came here.”

For some participants, their institutional choice was limited to MRU. Lamia expressed that, "I did not pick MRU... for me I told them [SACM] I just want to study in the U.S. because this scholarship program they give you the choice in the country but not the institution." Similarly, Nasser shared that "the minister of higher education brought [him] to MRU. [He didn't] have any knowledge of MRU before.” For many students with KASP funding, they did not feel they had an option as to which institution to apply to and could only suggest specifics for extenuating circumstances.

\section{Institution Level Influences}

Reputation for education over institutional ranking. The participants were not aware of various Carnegie classifications of institutions and assumed that all graduate programs were research-based but they had an awareness of institutional rankings. The male participants considered institutional ranking slightly more than the women, but it was the men who in the end said that the ranking did not matter. One student expressed skepticism about how rankings work and what matters for a graduate student. Marwan said,

For my personal point of view about rankings, I don't care what's the rank of the university, or whatever, I do care about who's my teacher and who is my advisor. So I was told that some of the [ranking] checklist or rubric that they use that gives the university [its] ranking, is the football team. ...I don't care about the football team. I do care about who's the person that gives me the knowledge. That's my biggest concern.

As Marwan later said, “It [the institution] doesn't have that prestige as a top ten university but it does have the quality to study and to gain the knowledge and do research."

While many of the graduate students considered institutional ranking, the fact that they did not gain acceptance into higher-ranking institutions meant that they focused on program quality rather than rankings. As Reem shared, "They [financial sponsor] asked me to look to the ranks but because I didn't get acceptance from them, there is no other university that offered [specific program].”

What worked in the favor of MRU was that because it was a teaching focused institution and a former normal school, it had a wellknown reputation for education. For example, Nasser, discussed his appreciation for the blended praxis and theory he received, 
In Saudi Arabia, I wasn't satisfied with the education they provided us because they only give us a theoretical stuff without implementation. So when I was in the field teaching special ed students, I was struggling. I didn't know how to deal with them. There is nothing from the book [to help me]. It's totally different than the realities so I decided to seek another place to get the information to help me to be successful in my field. So, yeah, that's why I chose this [institution].

Given MRU's educational reputation and history, it stands to reason that $89 \%$ of all Saudi graduate students were in education departments at this institution

Institution Alums. Saudi MRU alums influenced twelve of the participants to select this institution for graduate education. Influential alums were friends, family members, or faculty and administrators in various Saudi institutions. Majed expressed an influence from two of these categories,

While I'm searching [for institutions], I met one of my friends who was a student at MRU and I asked him about the university in general and he recommended me to come here. I read about it. I found that there are some leaders, I would say, in our country who got their higher education from this university, especially the educational [faculty], so I made that decision at that time and then I applied and just I came.

Being influenced by alums who were friends or faculty was common. Marwan asked a friend who had "graduated from MRU [and] he suggested that is a good university to study and the environment here and the atmosphere [are] supportive to anyone to study here.” Marwan also had a recommendation from Saudi faculty, "back home at my work one of the professors in the college of education he graduated from special education department and he advised me to study here."

While three of the women and four of the men had close family members earn degrees in the U.S. generally, four of these participants had family members who were alumni of MRU. As Fahd explained,

At the beginning, my brother-in-law came here, he was searching for universities and some of his friends recommended MRU for him and then he came here and spent like six months. After that he called me and asked me about if I wanted to come with my wife and he recommended this university and my wife applied here, too. 
Given the pattern of mobility and scholarship funding for Saudi students, many of these participants' undergraduate faculty or current colleagues in Saudi Arabia obtained their graduate degrees in the U.S. and specifically from this institution. For example, Essa shared that four faculty members in his department back in Saudi Arabia earned degrees from this institution. Omar echoed this by saying that he "had recommendations from [his] professor who was studying before 1980 and the end of 1970 [at this institution] and in the 1990's a lot of professors from Saudi Arabia study at MRU.”

Cultural and Religious Expectations of Family and Gender. Gender norms and family expectations created additional cultural and religious influences on choice and decision making for the participants. Saudi women are required to have a male guardian present when traveling, especially outside of the country. This requirement meant that brothers, husbands, and sometimes fathers followed some women participants and for two of the men in this study, their wives started studying after they began.

Rana explained this requirement generally and what it meant for her educational process even though her sister was already studying at this institution,

We [Saudi women] can't leave our country. Like, if I'm married, my husband has to be here with me, like, the first day and then he can go back after he settled me down and there is a house, there is a car, there is everything. There's my sister here but he stayed for seven months and then he goes back because of his job they did not let him stay for longer. So I finish my English language and I start my Masters without him and finish my Masters without him and then I took like a break from May to May, like, a year after Masters. For my $\mathrm{PhD}$, he came with me. So yeah, but I can't leave my country without a sponsor and my dad died so my husband, he's my sponsor. So there are cultural things we can't do as woman - cannot leave the country or travel anywhere without any man.

Two other women had younger brothers travel to the U.S. with them and study for their undergraduate degrees while the sisters pursued graduate education.

Omar and Saad's wives began studying for their graduate degrees at MRU after the men enrolled. For Mohanad, it was important that both he and his wife receive acceptances at the same institution and same college. Five of the male participants followed their wives to the institution because the women were accepted or started studying first. Mohanad said that he “didn't have any plans to study but because [his] wife came to America to 
study so [he] came with her and then it's like a good opportunity for [him] to study so that's why [he's] studying." As Fahd said, "I stick with my wife because she is already studying here and I cannot go there [other institutions] and leave her here alone.” For many of these Saudi students, graduate education ended up being about educating the entire family in the U.S., from spouses to brothers to children enrolled in the local k-12 system.

\section{DISCUSSION AND IMPLICATIONS}

When considering students' decisions about where to study overseas, the present study reinforces that it is necessary to consider influencers beyond the usual push-pull reasons (Mazzarol \& Soutar, 2002) or human capital (Becker, 1993). While some of the influencers in this study may echo elements of these factors, theories commonly used in international student mobility studies fail to recognize cultural and religious influences. Instead, this study shows that influences are not always best explained by either of these theoretical concepts. For example, the common narrative that the U.S. has quality and prestigious higher education is a pull factor. Participants in the study shared this; however, studying in the U.S. connected to feelings that the students did not always have a choice in their selection or decision. These Saudi students were pursuing graduate degrees abroad for external people, organizations and their country, not primarily for themselves as individuals.

Transnationalism provides an alternative explanation to the commonly used human capital theory when looking at student mobility because transnationalism acknowledges that migrants do not disconnect from their home countries by moving to another country but rather maintain relationships, connections, and spheres of influence (Schneider, 2013). The fact that the KSA or Saudi higher education institutions fund most Saudi students requires that the students maintain cross-border activity and engagement. In addition, the KASP scholarships fund yearly round trip flights home thereby ensuring personal relationships and regular physical cross-border movement. Having SACM as a mediator between KSA government officials or institutional administrators and U.S. institutions functions much differently than one-directional push or pull factors can explain.

Much of the student mobility literature discusses the decision to study abroad and the decision to study at specific institutions or in a specific discipline as an individual's choice (Chen, 2007; Lee, 2008). However, in the Saudi context, some participants expressed study abroad, institution, or program of study selection not as their choice but as a requirement of their government, SACM, or their university employer as the financial sponsor or as dictated by policies and terms of sponsorship. The participant's 
willingness to comply may reflect Saudi Arabia's collectivist societal norms that minimize the focus on individualism for the good of the greater group (Hofstede, 2003). The findings also expand understanding and conceptualizations of international student study abroad choice and decision-making.

As consistent with institutional isomorphism (DiMaggio \& Powell, 1983), many midlevel U.S. higher education institutions worry about increasing their overall ranking and type, Saudi graduate students may be willing to forgo this for quality program faculty instead and for recommendations from personal contacts. Less highly ranked institutions may want to conduct a scan of their reputation as perceived by international students and use that information to recruit for fields that already have a known reputation as opposed to trying to recruit in areas that are not ranked and do not have known quality programs or faculty. The opportunity for U.S. institutions to enroll Saudi students until 2020, presents an opportunity for mid-ranked institutions to grow Saudi student numbers by focusing on programs of reputation, quality, and uniqueness. Also related to recruiting, a collectivist society such as Saudi Arabia would value the personal relationships over the institutional or organization reputation (Hofstede, 2003); therefore, presenting an opportunity for U.S. institutions to foster Saudi alumni relationships.

Finally, while King Abdullah bin Abdul Aziz had a significant influence on expanding Saudis access to higher education and growing KSA's own system, he did so with the goal to preserve Saudi values, culture, religion, and traditions (Onsman, 2011). Saudi cultural and religious expectations or requirements clearly influenced decisions for many of the participants and influenced where a person studied and who chose to study there because of them. One dissertation found that two main reasons Saudi students study overseas were to better serve their country and to enhance their religious beliefs (Aktarkhavari, 1994). This finding has largely been absent from the research on international student mobility choice as it provides a culturally specific explanation to the influence of Muslim religion and culture for Saudi students. As family solidarity is a traditional Saudi value (Al-Banyan, 1980; Shaw, 2010), U.S. institutions could see an increase in Saudi students if they market themselves for family units and provide admissions counselors with culturally appropriate language and understanding.

Further, a better understanding of the familial focus of Saudi students as more communal may have potential to not only increase participation of Saudi students, but also provide opportunities for women to be educated at an advanced level. Our participants emphasized the importance of women having a guardian traveling with them until they are settled and the situation of a wife traveling with her husband who is a 
student. The decision for any trailing family member to also attend higher education demonstrates the transnational and non-linear decision making process. Acknowledging these values, U.S. institutions could seek to accommodate the temporary stay of a husband, brother or other male relative in their housing options or provide a potential "family deal" should more than one family member decide to study at the host institution. Or could actively reach out to the wives of male students. While our participants shared a few pieces on the gender differences related to travel and accommodations this study did not seek to focus on gender difference beyond understanding that gender played a role as to how a Saudi student began their study on a U.S. campus.

This study on Saudi graduate students reconceptualizes the homogenous perspectives on international student mobility to demonstrate that decisions are not made from just push-pull or economic factors. These Saudi students made study abroad choices based on culturally specific social processes involving various actors, both in and beyond their home country as well as intermediaries such as SACM who functions on behalf of KSA within the U.S. borders.

\section{REFERENCES}

Aktarkhavari, N. B. (1994). The perceptions of education and satisfaction of Saudi graduates: A comparative study of Saudi graduates from American and Saudi universities. (Doctoral dissertation). Retrieved from ProQuest, UMI Dissertations Publishing.

Al-Banyan, A. S. (1980). Saudi students in the United States: A study of crosscultural education and attitude change. London: Ithaca Press.

Al-Nusair, D. M. (2000). An assessment of college experience and educational gains of Saudi students studying at U.S. colleges and universities (Doctoral dissertation). Retrieved from The George Washington University, ProQuest, UMI Dissertations Publishing. (9955796).

Altbach, P. G. (2004). Higher education crosses borders. Change, 36(2), 18-24.

Becker, G. S. (1993). Human capital: A theoretical and empirical analysis, with special reference to education (3rd ed.). Chicago, IL: UCP.

Becker, R., \& Kolster, R. (2012). International student recruitment: Policies and developments in selected countries. The Hague, the Netherlands, Nuffic.

Bista, K., \& Dagley, A. (2015). Higher education preparation and decision making trends among international students. College \& University, 90(3), 2-11. Available at: http://works.bepress.com/bista/45/

Broido, E. M., \& Manning, K. (2002). Philosophical foundations and current theoretical perspectives in qualitative research. Journal of College Student Development, 43 (4), 434-445.

Brooks, R., \& J. Waters. (2011). Student mobilities, migration and the internationalization of higher education. Basingstoke: Palgrave Macmillan. doi:10.1057/9780230305588. 
Chen, L. H. (2007). East-Asian students' choice of Canadian graduate schools. International Journal of Educational Advancement, 7(4), 271-306.

Creswell, J. W. (2014). Research design: Qualitative, quantitative, and mixed methods approaches ( $4^{\text {th }}$ ed.). Thousand Oaks, CA: Sage Publications Inc.

Denman, B. D., \& Hilal, K. T. (2011). From barriers to bridges: An investigation on Saudi student mobility (2006-2009). International Review of Education, 57(3-4), 299-318.

DiMaggio, P. \& Powell, W. (1983). The iron cage revisited: Institutional isomorphism and collective rationality in organizational fields. American Sociological Review, 48(2), 147-160.

Eder, J., Smith, W. W., \& Pitts, R. E. (2010). Exploring factors influencing student study abroad destination choice. Journal of Teaching in Travel \& Tourism, 10(3), 232-250. doi: 10.1080/15313220.2010.503534

Elyas, T. (2008). The attitude and the impact of the American English as a global language within the Saudi education system. Novitas-ROYAL, 2(1), 28-48.

Gargano, T. (2009). (Re)conceptualizing international student mobility: The potential of transnational social fields. Journal of Studies in International Education, 13(3), 331-346.

Gibbs, G. (2007). Analyzing qualitative data. Thousand Oaks, California: Sage Publications Inc.

Hagedorn, L. S., \& Zhang, L. Y. (2011). The use of agents in recruiting Chinese undergraduates. Journal of Studies in International Education, 15(2), 186202. Doi: $10.1177 / 1028315310385460$

Hall, T. R. (2013). Saudi male perceptions of study in the United States: An analysis of King Abdullah scholarship program participants. (Unpublished doctoral dissertation). Western Kentucky University, Bowling Green, Kentucky.

Heyn, M. E. (2013). Experiences of male Saudi Arabian international students in the United States. (Doctoral dissertation). Retrieved from Proquest. (3572541).

Higher Education Council in Saudi Arabia. (1997). The regulations of scholarship and training for employees of universities. Retrieved from http://sponsorships.kau.edu.sa/Content.aspx?Site_ID=303\&lng=EN\&cid=2 301

Hofer, J. V. (2009). The identification of issues serving as barriers to positive educational experiences for Saudi Arabian students studying in the state of Missouri. (Doctoral dissertation). Available from ProQuest Dissertations and Theses database.

Hofstede, G. (2003). Culture's consequences: Comparing values, behaviors, institutions and organizations across nations. Thousand Oaks, CA: Sage Publications

Institute of International Education. (2015). Open doors data: Fact sheet by country 2015. Retrieved from http://www.iie.org/ /media/Files/Corporate/OpenDoors/Fact-Sheets-2015/Countries/Saudi-Arabia-Open-Doors-2015.pdf.

Jones, S. R., Torres, V., \& Armino, J. (2006). Negotiating the complexities of qualitative research in higher education: Fundamental elements and issues. New York, NY: Routledge.

King Abdullah Scholarships Program. Retrieved from Portal of the Saudi Ministry of Higher Education: http://www.mohe.gov.sa/ar/studyaboard/KingAbdulla-hstages/Pages/NinthStage.aspx 
Lee, E. (1966). A theory of migration. Demography, 3(1), 47-57. doi: $10.2307 / 2060063$

Lee, J. J. (2008). Beyond borders: International student pathways to the United States. Journal of Studies in International Education,12(3), 308-327. doi: 10.1177/1028315307299418

Lincoln, Y. S., Lynham, S. A., \& Guba, E. G. (2011). Paradigmatic controversies, contradictions, and emerging confluences, revisited. In N. K. Denzin and Y. S. Lincoln (Eds.), The Sage Handbook of Qualitative Research (pp. 97128). Thousand Oaks, CA: Sage.

Maxwell, J. A. (2004). Qualitative research design: An interactive approach. Thousand Oaks, CA: Sage.

Mazzarol, T., \& Soutar, G. N. (2002). "Push-pull” factors influencing international student destination choice. The International Journal of Educational Management, 16(2), 82-90. Doi: 10.1108/09513540210418403

Merriam, S. B. (2009). Qualitative research: A guide to design and implementation (2nd ed.). San Francisco, CA: Jossey-Bass.

Onsman, A. (2011). It is better to light a candle than to ban the darkness: Government led academic development in Saudi Arabian universities. Higher Education, 62(4), 519-532. Doi: 10.1007/s10734-010-9402-y

Onsman, A. (2012). Distributing the future evenly: English as the lingua franca in the Saudi Arabian higher education sector. Higher Education Policy, 25, 477-491. doi 10.1057/hep.2012.8

Patton, M. Q. (2001). Qualitative research and evaluation methods, 3rd ed. Thousand Oaks, CA: Sage Publications.

Paulsen, M. B. (2001). The economics of the public sector: The nature and role of public policy in the finance of higher education. In M. B. Paulsen \& J. C. Smart (eds.), The finance of higher education: Theory, research, policy, and practice (pp. 95-132). New York: Springer.

Perna, L. W., Orosz, K., Gopaul, B., Jumakulov, Z., Ashirbekov, A. \& Kishkentayeva, M. (2014). Promoting human capital development: A typology of international scholarship programs in higher education. Educational Researcher, 43(2), 63-73. doi 10.3102/0013189X14521863

Perna, L. W., Orosz, K., Jumakulov, Z., Kishkentayeva, M., \& Ashirbekov, A. (2015). Understanding the programmatic and contextual forces that influence participation in a government-sponsored international studentmobility program. Higher Education, 69(2), 173-188. doi 10.1007/s10734014-9767-4

Pimpa, N. (2003). The influence of peers and student recruitment agencies on Thai students' choices of international education. Journal of Studies in International Education, 7(2), 178-192. doi $10.1177 / 1028315303007002005$

Rasheed, M. A. (1972). Saudi students in the United States: A study of their perceptions of university goals and functions. Dissertation Abstracts International, 33, 6135.

Saudi Arabian Cultural Mission. (n.d.) Saudi Students Guide. Retrieved from http://www.sacm.org/pdf/studentsguide_english.pdf.

Saudi Arabian Cultural Mission (n.d.). Advancement of Saudi Women. Retrieved 
from Saudi Arabian Cultural Mission web site: http://www.sacm.org/ArabicSACM/pdf/women_front_web.pdf.

Schneider, C. (2013). Researching transnationalisation and higher education in the context of social mechanisms. Journal of Contemporary European Studies, 21(4), 480-495.

Shanka, T., Quintal, V., \& MEdMan, R. T. (2006). Factors influencing international students' choice of an education destination: A correspondence analysis. Journal of Marketing for Higher Education, 15(2), 31-46.

Shaw, D. (2010). Bridging differences: Saudi Arabian students reflect on their educational experiences and share success strategies. Dissertation Abstracts International, 71(4-A), 1192.

Urias, D., \& Yeakey, C. C. (2009). Analysis of the U.S. student visa system: Misperceptions, barriers, and consequences. Journal of Studies in International Education, 13(1), 72-109. doi 10.1177/1028315307308135

Wei, H. (2013). An empirical study on the determinants of international student mobility: A global perspective. Higher Education, 66(1), 105-122. doi 10.1007/s10734-012-9593-5

Wilkins, S., \& Huisman, J. (2011). International student destination choice: the influence of home campus experience on the decision to consider branch campuses. Journal of Marketing for Higher Education, 21(1), 61-83. doi 10.1080/08841241.2011.573592

Yakaboski, T. (2013). The rest of they story: A qualitative study of Chinese and Indian women's graduate education migration. NASPA Journal About Women in Higher Education, 6, 166-184. doi: 10.1515/njawhe-2013-0012.

Zhou, J. (2015). International students' motivation to pursue and complete a Ph.D. in the U.S.Higher Education, 69(5), 719-733. doi 10.1007/s10734-0149802-5

TAMARA YAKABOSKI, Ph.D., is an Associate Professor in Higher Education and Student Affairs Leadership at the University of Northern Colorado. She researches and teaches graduate seminars on student affairs, women's issues, and international higher education and the internationalization of universities. Email: Tamara.Yakaboski@unco.edu

KARLA PEREZ-VELEZ, is a Ph.D. candidate in Higher Education and Student Affairs Leadership at University of Northern Colorado. Email: pere0670@bears.unco.edu

YOUSEF ALMUTAIRI, is a Ph.D. candidate in Higher Education and Student Affairs Leadership at University of Northern Colorado. Email: almu4680@bears.unco.edu 